\title{
Chondrosarcoma of the Nasal Septum
}

\author{
Tae Hoon Kim ${ }^{1}$ D, Ki Jin Kwon ${ }^{1}$, Sung-Jig Lim ${ }^{2}$, and Kun Hee Lee ${ }^{1}$ iD \\ ${ }^{1}$ Departments of Otorhinolaryngology-Head and Neck Surgery, ${ }^{2}$ Pathology, College of Medicine, \\ Kyung Hee University Hospital at Gangdong, Seoul, Korea
}

\section{비중격에 발생한 연골육종 1예 \\ 김태훈 ${ }^{1} \cdot$ 권기진 $^{1} \cdot$ 임성직 $^{2} \cdot$ 이건희 ${ }^{1}$ \\ 강동경희대학교병원 이비인후과, ${ }^{1}{ }^{\text {병리과 }{ }^{2}}$}

\author{
Received April 23, 2020 \\ Revised August 3,2020 \\ Accepted August 5, 2020 \\ Address for correspondence \\ Kun Hee Lee, MD, PhD \\ Department of Otorhinolaryngology- \\ Head and Neck Surgery, \\ College of Medicine, \\ Kyung Hee University \\ Hospital at Gangdong, \\ 892 Dongnam-ro, Gangdong-gu, \\ Seoul 05278, Korea \\ Tel $+82-2-440-6181$ \\ Fax $+82-2-440-7325$ \\ E-mailnose4u@gmail.com
}

Chondrosarcoma of the nasal septum is a very rare malignant tumor in the head and neck region. To diagnose chondrosarcoma, it is challenging to obtain an exact initial impression just by simple physical examination. Therefore, imaging studies are useful in the initial assessment of chondrosarcoma. Pathological confirmation is necessary for a definitive diagnosis of chondrosarcoma. In the treatment of chondrosarcoma, complete surgical resection is most effective, but often difficult. We report a patient with chondrosarcoma misdiagnosed with nasal septal deviation causing nasal obstruction. The patient underwent endoscopic surgical resection via an external rhinoplasty approach. The pathological diagnosis of the patient was chondrosarcoma with pathological Grade 1 . The patient has been regularly followed up to date without recurrence. Korean J Otorhinolaryngol-Head Neck Surg 2021;64(6):433-8

\section{서 론}

연골육종(chondrosarcoma)은 비상피성 유래 종양으로 성 장이 느리고 주로 골반, 늑골, 사지의 장골, 견갑골, 그리고 흥골에 발생하는 악성 종양이다. 뼈에 발생하는 원발성, 악성 종양 중 대략 $11 \%$ 차지하며, 골육종(osteosarcoma)에 이어서 두 번째로 흔한 뼈에 발생하는 육종(sarcoma) 중 하나이다. ${ }^{1)}$ 두경부 영역에서 발생은 오직 5 10\% 정도만 보이는 드문 질 환이며, 특히 비중격에서 발생은 극히 드물다고 알려져 있다. 주로 중년의 남성에서 발생되었다는 보고가 있으나 병의 발생 적 원인은 아직 잘 알려지지 않았다. 현재는 중간엽 줄기세포 (mesenchymal stem cell)에서 연골의 발생 중 유래되거나 비 정상적인 조직 분화 과정에서의 기원으로 추측하고 있다. ${ }^{2-4)}$

This is an Open Access article distributed under the terms of the Creative Commons Attribution Non-Commercial License (https://creativecommons.org/licenses/by-nc/4.0) which permits unrestricted non-commercial use, distribution, and reproduction in any medium, provided the original work is properly cited.
우리는 젊은 여성에게서 다른 장기의 침범없이 비중격에 국한된 연골육종을 최소한의 비주절개를 통하여 내시경적 으로 병변을 완전절제하였고 다른 보조요법 없이 치료 후 추 적 관찰 중인 사례를 보고하고자 한다.

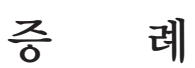

27세 여자 환자가 내원 2개월 전부터 양측 비폐색으로 타 병원에서 비중격 만곡증을 진단받고 약물치료로 경과 관찰 하던 중 증상이 지속되어 의뢰되었다. 과거력과 가족력에서 특이 사항은 없었고 내원 당시 양측 비폐색과 수양성 비루, 간헐적인 두통을 호소하였으나, 비출혈, 시력저하, 복시, 안면 통증, 체중감소 이력은 없었다. 내시경을 이용한 이학적 검사 에서 비중격이 좌측으로 편위되었고(Fig. 1), 우측 비강 내에 는 견고하며 점막으로 싸여있는, 표면이 매끈한 종물로 채워 져 있었다. 표면은 미세혈관이 관찰되었고 정상적인 비중격과 
의 경계가 불명확하였다. 비인두는 정상 소견이고 구강 내에 서도 경구개 및 연구개 이상은 확인되지 않았다. 안구 운동도 정상이며, 이경 검사에서도 특이 사항은 확인되지 않았다. 경 부에서 촉진되는 림프절은 없었고, 환자의 전반적인 상태에서 다른 이상소견은 확인할 수 없었다.

부비동 조영 증강 컴퓨터단층촬영(computed tomography, $\mathrm{CT}$ )에서는 석회화를 중심 부위에 동반하는 저음영의 기질이 비중격 및 비강의 전방 부위까지 확장되어있고, 그 주위 일 부에서 조영 증강된 병변(최대직경 약 $4 \mathrm{~cm}$ )이 확인되었다. 이로 인해 좌측으로 비중격이 편위되어 있었고, 좌측 상악동 내측 벽과 우측 비강 하부의 골부 일부까지 연접되었으나 두 개저 골파괴 소견은 없었다(Fig. 2).
이와 같은 소견을 종합하여 골연골종(osteochondroma), 연골종, 연골육종 등을 의심하에 전신마취하 수술적 조직검 사 및 완전절제를 계획하였다. 병변이 비강의 하부까지 위치 하여 내시경적 접근법으로는 완전절제가 되지 않을 것으로 판단되어 비외접근법의 일종인 Padovan 절개를 통한 접근법 을 이용하여 종양 적출술을 시행하기로 하였고 비중격과의 연접을 고려하여 비중격절제술(septectomy)도 계획하였다. 수술 중 비중격에서 기원한 종물이 비중격 연골, 사골수직판, 서골, 상악골릉의 일부를 침범하여 견고하게 부착된 상태로 비중격을 좌측으로 밀고 있었으나 좌측 비강 내 확인된 병변 은 없었으며, 내시경을 이용하여 완전히 제거하였다. 그러나 병변이 쉽게 부서지기 쉬운 형태로 en bloc으로 제거할 수는
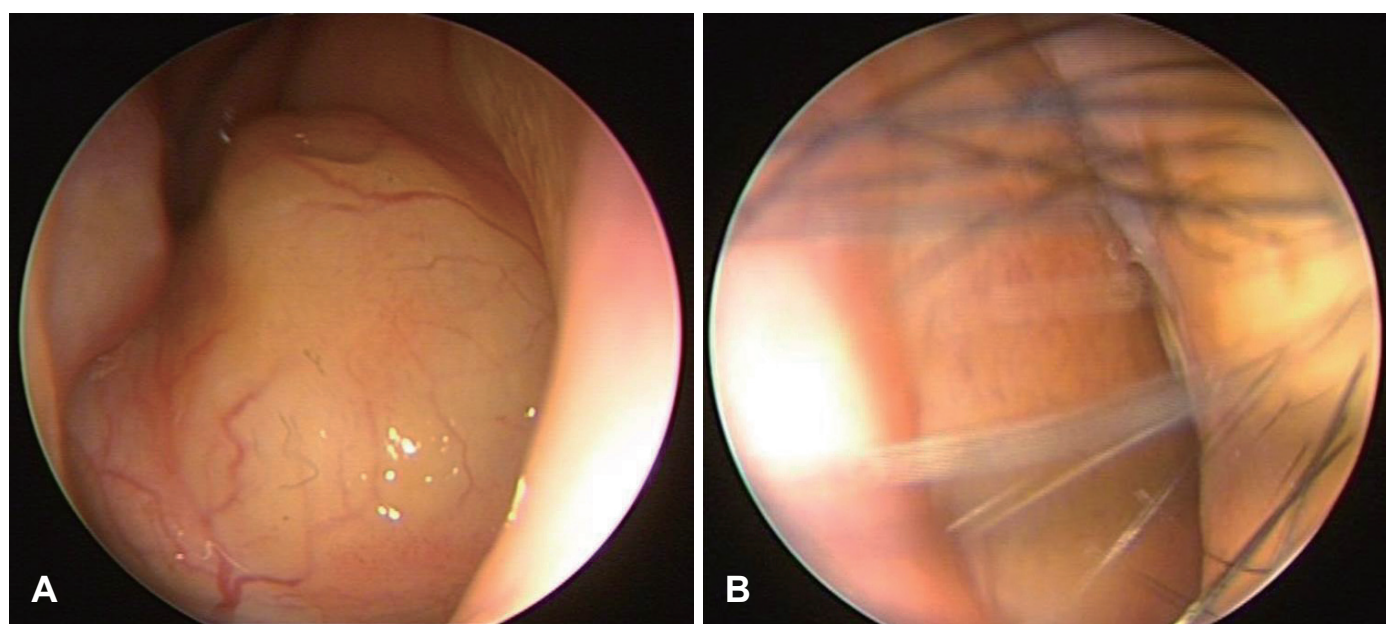

Fig. 1. Endoscopic findings. Pre-operative nasal endoscopy findings reveal a firm smooth-surfaced mass in the right nasal cavity (A). The left nasal cavity is narrow due to the severely deviated nasal septum (B).
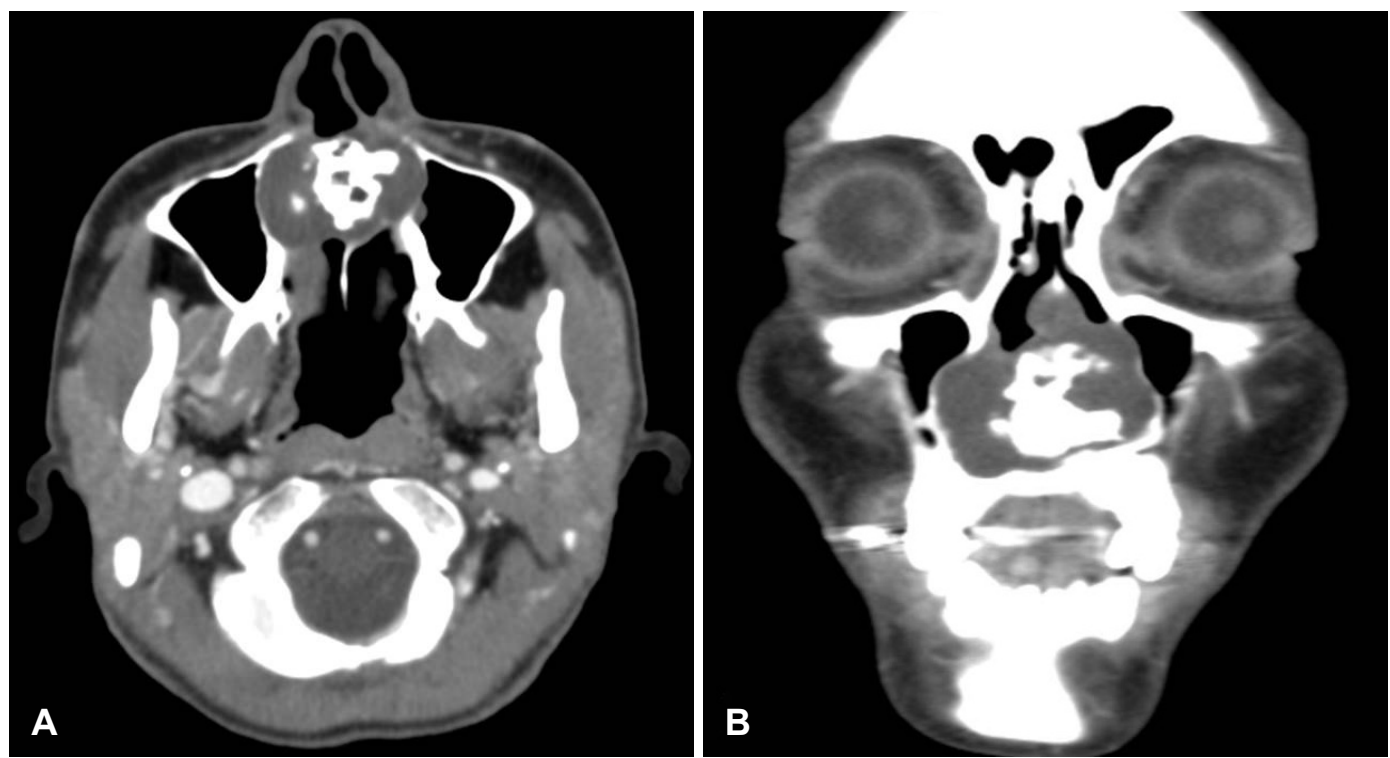

Fig. 2. Preoperative paranasal sinus contrast-enhanced CT scans. Axial (A) and coronal (B) views show an approximately 4-cm-sized expansible low-density mass filling the anterior nasal cavity. A soft tissue mass with calcifications and septal destruction in nasal cavity are observed. 
없었다(Fig 3). 술자는 병변 부위를 모두 제거하는 데 초점을 두었고 내시경적으로 종양의 광범위한 완전절제를 시행하였 다. 수술 과정에서 종양과 접한 비강 점막, 비중격 연골, 우측 하비갑개의 일부도 제거가 되었고, 좌측은 수술중 비중격 점 막 열상이 동반되었으나 크기가 작아 단순 봉합을 시행 후 silastic sheet를 양측에 삽입 및 흡수성 비강 패킹을 이용하 여 수술을 종료하였다. 수술 후 1 일째 출혈 및 다른 합병증 증상 없이 퇴원하였다. 술후 병리조직검사상 Grade I의 연골 육종으로 진단되었다(Fig. 4). 수술 후 남아 있는 병변 및 타 장기 전이를 확인하기 위해 양전자방출 컴퓨터단층촬영(positron emission tomography, PET)하였으나 비강 근처의 과 대사(hypermetabolism) 및 림프절 원격전이 부위는 없었다. 현재 수술 후 6개월째 외래에서 추적 관찰 중으로 비중격 천 공은 발생하지 않았고 종양의 재발 소견은 확인되지 않았다 (Fig. 5).

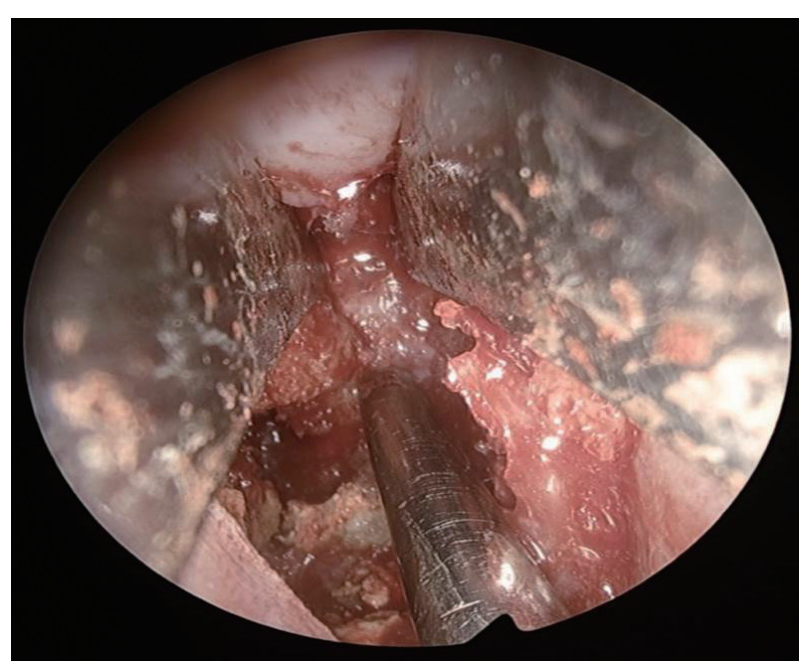

Fig. 3. Intraoperative findings. A whitish soft mass is observed in the right nasal cavity.

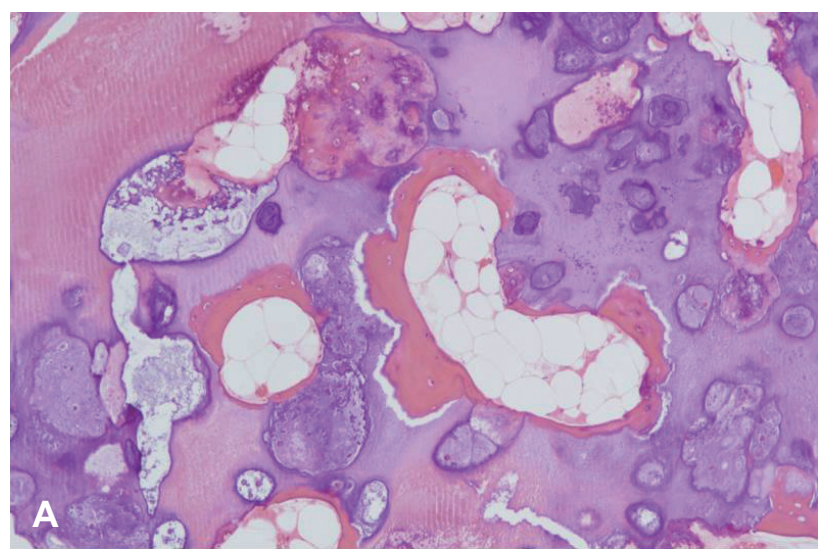

\section{고 찰}

문헌에 보고된 비중격에 발생한 연골육종은 대략 63건으 로 매우 드물게 발생함을 알 수 있다.5) 임상 증상은 주로 종 양이 발생하는 부위와 그 크기로 인한 인접한 영향으로 나타 난다. 비강 내에서는 비폐색이 가장 흔한 증상이며, 이외에도 두통, 비출혈, 후각저하, 안면통, 시야 손상 및 뇌신경 징후까 지 다양하다. 천천히 진행되는 질병 양상과 증상도 다양하며 비특이적이기 때문에, 일반적으로 1 차 의료 수준에서 다른 질환으로 오인될 가능성이 크다. 본 사례도 환자는 지속적인 비폐색을 주호소로 비중격 만곡증을 치료하기 위한 수술을 고려하고 외래를 내원하였다.

증상과 이학적 검사상으로는 진단의 어려움이 있기에 영상 학적 분석이 평가와 치료 계획을 세우는 데 도움이 된다. CT 에서는 전형적으로 저음영(low-attenuated)의 기질에 석회화 (calcification)된 부위가 혼합되어 있으며, 골미란과 골파괴가 관찰되기도 한다. 자기공명영상(magnetic resonance imaging, MRI)은 종양의 침범 정도와 두개 내 포함 여부를 정확 하게 보여준다. T1 강조영상(T1-weighted images)에서는 저 신호 강도의 음영을 보이며, T2 강조영상(T2-weighted images)서는 고신호 강도를 보인다. ${ }^{\text {() }}$ 일반적으로는 CT만으로도 어느정도 예측이 가능하지만, 병변의 특징이 모호하게 나타 날 경우에는 MRI도 추가적으로 필요하다. MRI에서는 두 가 지 조영 증강 방법에서 다른 신호 강도를 나타내기 때문에 병 변의 경계를 확인하는 데 도움이 된다. ${ }^{6-8)}$ 이 환자는 CT에서 전형적인 연골육종의 소견을 보이고 병변이 비강 내에만 국 한된 양상으로 수술 전 MRI 촬영을 추가적으로 시행하지 않 았다. 최근에는 $\mathrm{PET}$ 이 연골성 종양의 병기 설정과 결과 예측 에 도움이 된다는 보고도 있었다. 이들은 최대 standardized uptake value 값을 기준으로 하여 양성과 악성을 분류하는

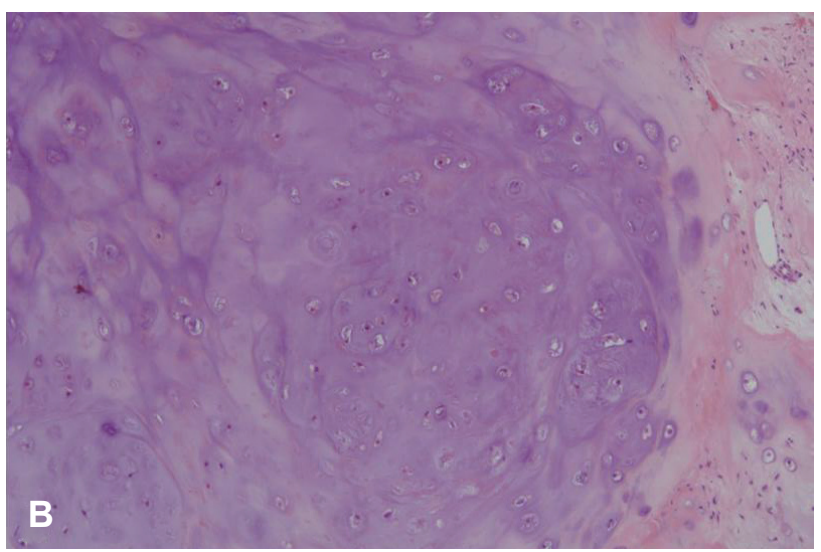

Fig. 4. Histopathological examination of the specimen with hematoxylin and eosin staining (both $\times 100$ magnification). Tumor cells show an infiltrative growth pattern encasing the trabecular bones and scalloping (A). Nodular growth of neoplastic cells in the lacunae and surrounding the chondroid matrix. The tumor is hypocellular and tumor cells have small and dark nuclei without mitosis (B). 

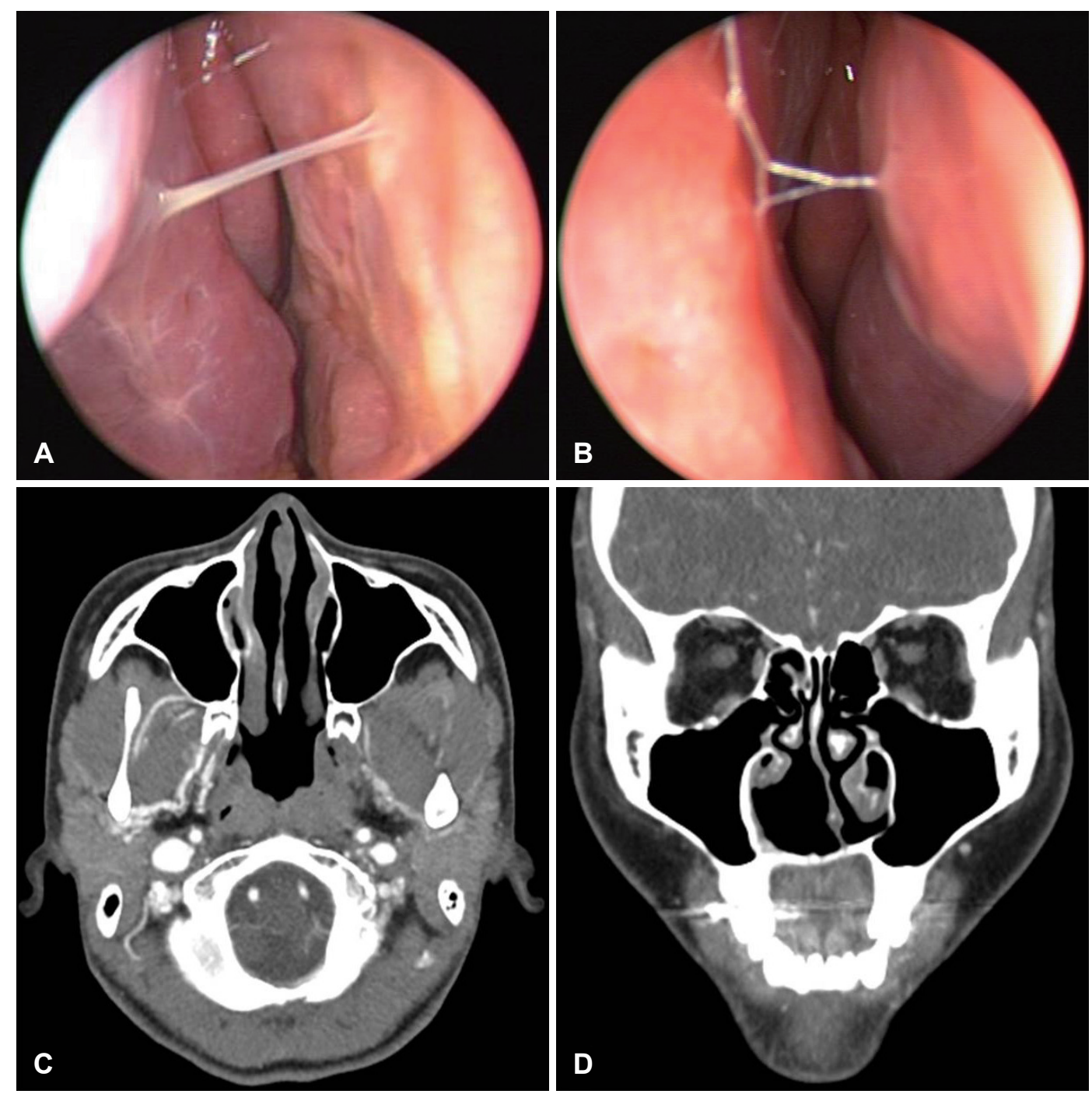

Fig. 5. Post-operative follow-up (6 months) findings. Nasal endoscopic examination showing complete removal of the tumor with no evidence of recurrence (A, right; $B$, left). Paranasal sinus contrast-enhanced CT scans (C, axial; $D$, coronal) show no enhancing lesion on the operative site.

\section{데 이용하기도 하였다. ${ }^{9}$}

영상학적인 자료를 통해서 추정진단을 하였으나 감별진단 을 위해서는 정확한 조직학적 판독이 필요하다. 외래에서 간 단하게 생검이 가능한 사례도 있었으나, 저자는 샘플 오류의 가능성과 충분한 조직을 확보하기에는 보다 안전한 수술적 생검을 시행했다. 이를 통하여 비강에 발생할 수 있는 연골양 척삭종(chondroid chordoma) 연골종(chondroma), 척삭종 (chordoma), 연골점액유사섬유종(chondromyxoid fibroma) 등의 질환과 감별진단을 할 수 있다. ${ }^{10)}$ 연골육종은 엽상(lobulated) 성장 양상, 과세포도(hypercellularity), 세포학적 이 형성(atypia)를 보인다. 그리고 세포도, 핵의 크기, 이형성, 세 포 분열의 활동 정도에 따라 Grade를 I, II, III로 분류할 수 있다.11,12) 병기설정은 American Joint Committee on Cancer 의 기준을 따른다. ${ }^{13)} \mathrm{TNM}$ 병기설정을 기준으로 악성 림프종 (malignant lymphoma)과 다발성 골수종(multiple myelo$\mathrm{ma}$ )을 제외한 뼈에 발생하는 모든 원발종양(primary tumor) 이 이에 속한다. 원발종양의 정의는 발생한 해부학적 위치에 따라 첫 번째는 팔다리뼈대(appendicular skeleton), 사지 (trunk), 두개골(skull), 얼굴뼈(facial bone), 두 번째는 골반 (pelvis), 그리고 세 번째는 척추(spine)으로 $\mathrm{T}$ 분류를 장경의 길이를 기준으로 한다. 림프절 전이 $(\mathrm{N})$ 는 국소 림프절 전이의 유무에 따라 분류되고, 원격전이 $(\mathrm{M})$ 는 타 장기로 전이 유무 에 따라 분류된다. 하지만 다른 사례 연구들에서도 병기설정 에 대한 분석은 충분히 이루어지지 않았다. ${ }^{5)}$

표준치료는 수술이며, 병변을 포함하여 광범위하게 완전절 제하는 것이 중요하다. 수술 후 방사선치료 및 항암치료도 있 지만 제한적이며, 주로 재발이나 남아있는 병소를 치료하기 위한 보조적인 역할을 한다. ${ }^{10,14)}$ 외측비절제술(lateral rhi- 
notomy), Weber-Ferguson 접근법, 구순하 경비적(sublabial transnasal) 접근법, 전방 두개안면(anterior craniofacial) 접 근법 등 현재까지 많은 수술적 접근법이 문헌에 보고되었다. ${ }^{15)}$ 수술방법의 선택은 원발 종양의 침범 범위에 따라 결정되는 데, 대부분은 개방적 접근을 이용하여 수술하였다. 최근에는 네비게이션을 이용한 내시경이 발달하면서 최소 침습적인 수 술법이 증가하고 있다. 23) 이는 기존처럼 안면 및 구강 내 절 개가 없기 때문에 빠른 회복과 미용적 측면에서 많은 이점이 있다. 더구나 해부학적 구조를 가능한 보존할 수 있어 미용 적으로나 비강의 정상 생리기능을 유지하기에 유리하다. ${ }^{16}$ 하 지만 내시경만으로 수술할 경우 종양의 광범위한 절제가 어 려워 positive margin으로 추가 방사선치료가 필요한 사례가 많았고 종양의 사이즈가 클 경우에도 제거에 어려움이 있었 다. ${ }^{5)}$ 저자들은 환자가 젊은 여성인 점과 병변이 비강 내 국한 되어 있기 때문에 침습적인 방법보다는 최소 접근법인 내시 경적 제거를 우선적으로 고려하였다. 하지만, 수술 전 영상에 서 비강 하부까지 침범한 병변을 완전절제하기 위해서는 추 가적인 접근 경로가 필요로 하다고 판단하여, 비외접근법 중 비주에 Padovan 절개를 넣어 접근하였다. 종양의 안전연을 확보하여 en bloc으로 절제를 하는 것이 중요하지만 병변이 부서지기 쉬운 형태로 광범위한 완전절제를 하는 데 초점을 두었다. 2018년 Stevenson 등기에 따르면 사지와 골반의 연골 육종의 경우는 안전연이 국소재발률에 영향을 주지만 질병 특이생존(disease specific survival)에 대한 영향은 Grade 2 이상에서만 영향을 주었고, Grade 1에서는 통계적인 생존률 의 이득이 없었다. 추가적으로 2017년 Chen 등 ${ }^{18}$ 의 메타분석 에서는 Grade I 연골육종의 경우 병소 내 절제(intralesional resection)과 광범위 절제 사이에 보조요법과 관련 없이 생존 률의 차이가 없었으며 병소 내 절제를 하더라도 전이 위험도 상승하지 않았다. 오히려 병소 내 절제의 경우 합병증 발생을 줄이고 더 나은 기능적 결과를 보였다. 더구나 비강 및 부비 동에서 발생한 경우에 적절한 안전연에 대한 보고는 아직까 지 없다. ${ }^{5)}$

수술 후 보조 치료법으로 방사선 치료에 대해 여러 견해가 있으나 연골육종의 세포 분화와 성장 속도가 느리기 때문에 방사선에 상대적 치료 저항성을 가진다고 알려져 있다. ${ }^{19)}$ 따 라서 수술 후 남아있는 병변이 확인이 될 경우와 수술적 치 료가 불가능한 크기의 환자들을 대상으로 완화 목적으로 사 용되는 경우가 많다. ${ }^{14)}$ 특히 본 사례처럼 저분화도의 연골육 종과 병변의 절제가 완전히 이루어진 경우에는 수술 후 방사 선 치료 적응증이 아니다. 항암 치료의 유용성도 이와 비슷 하다. 저분화도의 연골육종은 항암 저항성을 가지며, 임상적 으로 공격적인 종양과 빠른 국소 증식과 전이의 가능성이 높
은 경우에 고려할 수 있다. ${ }^{20)}$

다른 종양과 유사하게 예후에는 완전한 절제가 중요하다. 예후에 영향을 미칠 수 있는 요인으로는 진단 시 병기와 조직 학적 분화도, 병변의 크기 및 침습 범위가 있다. ${ }^{5)}$ 일반적으로 림프절 전이와 원격전이의 가능성은 낮다. 5년 전체생존(overall survival)은 대략 44 81\% 이며, 7 20\% 환자에서 주로 폐 와 뼈로 전이가 나타났다. 두경부 영역에 발생한 연골육종을 수술적 치료로 관찰한 결과 5년 생존율은 Grade I은 100\%, Grade II 또는 Grade III에서는 60\%로 보고된 바 있다. ${ }^{21}$ 재 발률은 Grade I에서 $17 \%$ 이며 국소 재발은 사망에 이르는 가 장 큰 요인이다. ${ }^{2,7)}$ 다른 사례 연구에서 수술적 치료만으로는 평균적으로 36.5 개월 동안 재발이 없었다고 알려져 있다.) 따 라서 수술 후 정기적인 내시경적 추적 관찰이 충분한 기간 동안 필요하다.

현재까지 두경부 영역 중 특히 비중격에 발생한 연골육종 의 사례가 많지 않았기에 진단 및 치료의 가이드라인이 부족 하다. 비특이적인 임상양상과 진단의 어려움으로 치료를 빠 르게 시작하는 것도 쉽지 않다. 그러나 연골육종은 분류상 악성 종양이며, 분화도에 따라 병의 진행이 다양하게 나타기 에 조기 진단과 정확한 치료방침의 설정이 중요하다. 더구나 병변의 위치가 안면부에 발생하기 때문에 수술적 치료에 있 어서도 미용적, 사회적인 측면을 고려하지 않을 수 없다. 이 증례는 드물게 젊은 여성에 발생한 경우로 최소한의 절개와 비내시경을 통해 병변을 완전절제한 것에 의의가 있다. 다만 본 사례의 경우 내시경상으로 정상 조직을 포함하여 충분히 제거한 것으로 판단하여 생략하였으나 동결 절편 검사를 시 행하여 안전연 경계를 확인하는 것이 좀 더 바람직했을 것이 다. 그리고 수술 후 추적 관찰의 기간이 짧기 때문에 장기간 의 추적 결과가 보충이 되어야 할 것이다. 마지막으로 비중격 에 발생한 연골육종에 대한 보다 전문적인 다학제적 접근과 표준치료방침이 필요할 것으로 생각된다.

\section{Acknowledgments}

None.

\section{Author Contribution}

Formal analysis: Sung-Jig Lim. Resources: Ki Jin Kwon. Writing—original draft: Tae Hoon Kim. Writing—review \& editing: Kun Hee Lee.

\section{ORCIDs}

Kun Hee Lee

https://orcid.org/0000-0002-5380-3726

Tae Hoon Kim

https://orcid.org/0000-0002-8352-3741

\section{REFERENCES}

1) Koch BB, Karnell LH, Hoffman HT, Apostolakis LW, Robinson RA, 
Zhen W, et al. National cancer database report on chondrosarcoma of the head and neck. Head Neck 2000;22(4):408-25.

2) Downey TJ, Clark SK, Moore DW. Chondrosarcoma of the nasal septum. Otolaryngol Head Neck Surg 2001;125(1):98-100.

3) Coppit GL, Eusterman VD, Bartels J, Downey TJ. Endoscopic resection of chondrosarcomas of the nasal septum: A report of 2 cases. Otolaryngol Head Neck Surg 2002;127(6):569-71.

4) Ali A, Gosavi M, Michael R, Mathew J, Kurien M, Korula A. Chondrosarcoma of the nasal septum. Indian J Otolaryngol Head Neck Surg 2004;56(4):314-6.

5) Khan MN, Husain Q, Kanumuri VV, Boghani Z, Patel CR, Liu JK, et al. Management of sinonasal chondrosarcoma: A systematic review of 161 patients. Int Forum Allergy Rhinol 2013;3(8):670-7.

6) Yamamoto $S$, Motoori $K$, Takano H, Nagata H, Ueda T, Osaka I. Chondrosarcoma of the nasal septum. Skeletal Radiol 2002;31(9): 543-6.

7) Kainuma K, Netsu K, Asamura K, Hayashi K, Takumi Y, Ota H, et al. Chondrosarcoma of the nasal septum: A case report. Auris Nasus Larynx 2009;36(5):601-5.

8) Dass AN, Peh WC, Shek TW, Ho WK. Case 139: Nasal septum low-grade chondrosarcoma. Radiology 2008;249(2):714-7.

9) Feldman F, Van Heertum R, Saxena C, Parisien M. 18FDG-PET applications for cartilage neoplasms. Skeletal Radiol 2005;34(7): 367-74.

10) Gelderblom H, Hogendoorn PC, Dijkstra SD, van Rijswijk CS, Krol AD, Taminiau AH, et al. The clinical approach towards chondrosarcoma. Oncologist 2008;13(3):320-9.

11) Rassekh CH, Nuss DW, Kapadia SB, Curtin HD, Weissman JL, Janecka IP. Chondrosarcoma of the nasal septum: Skull base imaging and clinicopathologic correlation. Otolaryngol Head Neck
Surg 1996;115(1):29-37

12) Hamilton JS, Osborne RF, Brown JJ. A rare case of rapidly progressive craniofacial chondrosarcoma. Ear Nose Throat J 2005;84(1):18-20.

13) Amin MB, Edge S, Greene F, Byrd DR, Brookland RK, Washington MK, et al. AJCC Cancer Staging Manual. 8th ed. Berlin: Springer; 2017. p.471-86.

14) Marco RA, Gitelis S, Brebach GT, Healey JH. Cartilage tumors: Evaluation and treatment. J Am Acad Orthop Surg 2000;8(5):292304.

15) Magnano M, Boffano P, Machetta G, Garibaldi E, Delmastro E, Gabriele P. Chondrosarcoma of the nasal septum. Eur Arch Otorhinolaryngol 2015;272(3):765-72.

16) Alqudah M, Odat $\mathrm{H}$, Issa I, Al-Qudah M. Extensive chondrosarcoma of the nasal septum: Endoscopic resection and long-term followup. J Craniofac Surg 2016;27(4):976-7.

17) Stevenson JD, Laitinen MK, Parry MC, Sumathi V, Grimer RJ, Jeys LM. The role of surgical margins in chondrosarcoma. Eur J Surg Oncol 2018;44(9):1412-8.

18) Chen $\mathrm{X}$, Yu LJ, Peng HM, Jiang C, Ye CH, Zhu SB, et al. Is intralesional resection suitable for central grade 1 chondrosarcoma: A systematic review and updated meta-analysis. Eur J Surg Oncol 2017;43(9):1718-26.

19) McNaney D, Lindberg RD, Ayala AG, Barkley HT Jr, Hussey DH. Fifteen year radiotherapy experience with chondrosarcoma of bone. Int J Radiat Oncol Biol Phys 1982;8(2):187-90.

20) Ruark DS, Schlehaider UK, Shah JP. Chondrosarcomas of the head and neck. World J Surg 1992;16(5):1010-5; discussion 1015-6.

21) Obeso S, Llorente JL, Díaz-Molina JP, Sánchez-Fernández R, Rodrigo JP, Suárez C. Surgical treatment of head and neck chondrosarcomas. Acta Otorrinolaringol Esp 2010;61(4):262-71. 